\title{
Task 3.15 - Impacts of Low-NOx Combustion on Fly Ash and Slagging
}

\author{
Semi-Annual Report \\ July 1 - December 31, 1996 \\ By \\ Christopher J. Zygarlicke \\ RECEIVED \\ DIIS 141997 \\ Donald P. McCollor
}

Work Performed Under Contract No.: DE-FC21-93MC30097

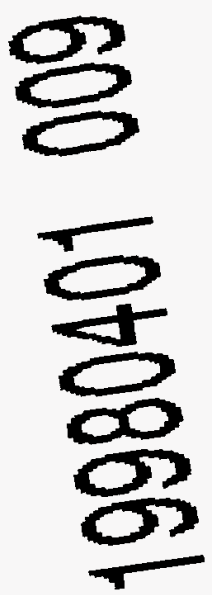

For

U.S. Department of Energy

Office of Fossil Energy

Morgantown Energy Technology Center

P.O. Box 880

Morgantown, West Virginia 26507-0880

By

Energy and Environmental Research Center

University of North Dakota

P. O. Box 9018

Grand Forks, North Dakota 58202-9018

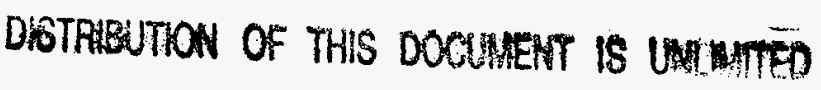

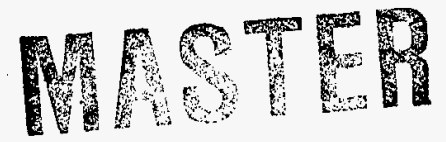




\section{Disclaimer}

This report was prepared as an account of work sponsored by an agency of the United States Government. Neither the United States Government nor any agency thereof, nor any of their employees, makes any warranty, express or implied, or assumes any legal liability or responsibility for the accuracy, completeness, or usefulness of any information, apparatus, product, or process disclosed, or represents that its use would not infringe privately owned rights. Reference herein to any specific commercial product, process, or service by trade name, trademark, manufacturer, or otherwise does not necessarily constitute or imply its endorsement, recommendation, or favoring by the United States Government or any agency thereof. The views and opinions of authors expressed herein do not necessarily state or reflect those of the United States Government or any agency thereof. 


\section{DISCLAIMER}

This report was prepared as an account of work sponsored by an agency of the United States Government. Neither the United States Government, nor any agency thereof, nor any of their employees makes any warranty, express or implied, or assumes any legal liability or responsibility for the accuracy, completeness, or usefulness of any information, apparatus, product, or process disclosed or represents that its use would not infringe privately owned rights. Reference herein to any specific commercial product, process, or service by trade name, trademark, manufacturer, or otherwise does not necessarily constitute or imply its endorsement, recommendation, or favoring by the United States Government or any agency thereof. The views and opinions of authors expressed herein do not necessarily state or reflect those of the United States Government or any agency thereof.

\section{ACKNOWLEDGMENT}

This semiannual was prepared with the support of the U.S. Department of Energy (DOE) Federal Energy Technology Center Cooperative Agreement No. DE-FC21-93MC30097. However, any opinions, findings, conclusions, or recommendations expressed herein are those of the author(s) and do not necessarily reflect the views of the DOE.

\section{EERC DISCLAIMER}

LEGAL NOTICE This research report was prepared by the Energy \& Environmental Research Center (EERC), an agency of the University of North Dakota, as an account of work sponsored by the U.S. Department of Energy. Because of the research nature of the work performed, neither the EERC nor any of its employees makes any warranty, express or implied, or assumes any legal liability or responsibility for the accuracy, completeness, or usefulness of any information, apparatus, product, or process disclosed, or represents that its use would not infringe privately owned rights. Reference herein to any specific commercial product, process, or service by trade name, trademark, manufacturer, or otherwise does not necessarily constitute or imply its endorsement or recommendation by the EERC. 


\section{TABLE OF CONTENTS}

LIST OF FIGURES $\ldots \ldots \ldots \ldots \ldots \ldots \ldots \ldots \ldots \ldots \ldots \ldots \ldots \ldots$

LIST OF TABLES $\ldots \ldots \ldots \ldots \ldots \ldots \ldots \ldots \ldots \ldots \ldots \ldots \ldots \ldots \ldots$

1.0 INTRODUCTION $\ldots \ldots \ldots \ldots \ldots \ldots \ldots \ldots \ldots \ldots \ldots \ldots \ldots \ldots \ldots$

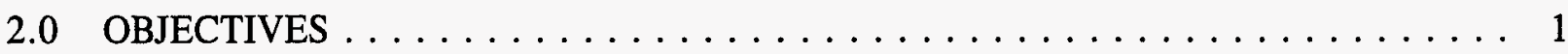

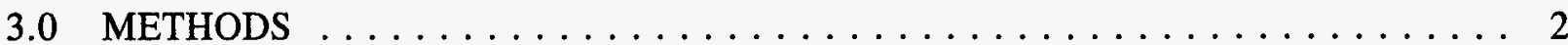

$4.0 \quad$ RESULTS $\ldots \ldots \ldots \ldots \ldots \ldots \ldots \ldots \ldots \ldots \ldots \ldots \ldots \ldots \ldots \ldots \ldots$

4.1 Boiler Industry Review $\ldots \ldots \ldots \ldots \ldots \ldots \ldots \ldots \ldots$

4.2 CEPS Conventional and Low-NO $\mathrm{NO}_{\mathrm{x}}$ Operating Conditions $\ldots \ldots \ldots \ldots$

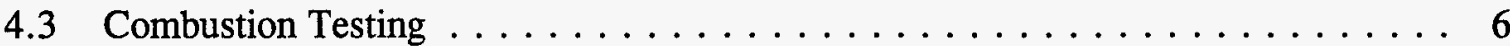

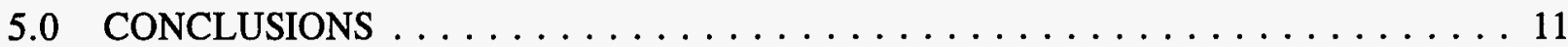

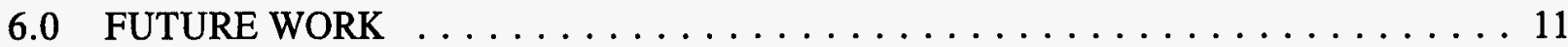

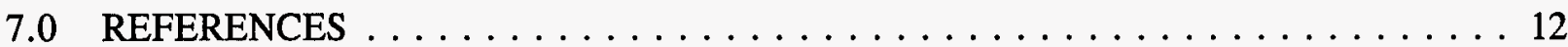

\section{LIST OF FIGURES}

1 Design sketch of the CEPS showing the main and convective pass sections, heat

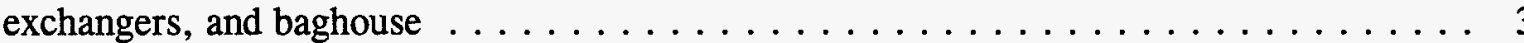

\section{LIST OF TABLES}

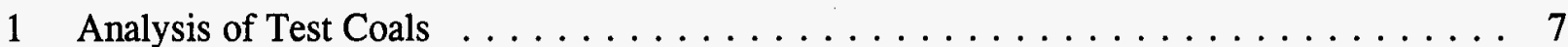

2 Combustion Test Conditions $\ldots \ldots \ldots \ldots \ldots \ldots \ldots \ldots \ldots \ldots \ldots \ldots \ldots$

3 Entrained Ash Analysis $\ldots \ldots \ldots \ldots \ldots \ldots \ldots \ldots \ldots$

4 SEMPC Analysis of Slag Deposits $\ldots \ldots \ldots \ldots \ldots \ldots \ldots \ldots$ 


\section{SUBTASK 3.15 - IMPACTS OF LOW-NO ${ }_{\mathrm{x}}$ COMBUSTION ON FLY ASH AND SLAGGING}

\subsection{INTRODUCTION}

With the advent of the Clean Air Act Amendments of 1990, the coal-fired power industry began a more accelerated move toward using low- $\mathrm{NO}_{\mathrm{x}}$ burner (LNB) technologies to reduce $\mathrm{NO}_{\mathrm{x}}$ emissions. Most LNBs incorporate less oxygen with the coal initially, creating a cooler and somewhat substoichiometric initial combustion zone, with additional oxygen added further on in the combustion process to complete char combustion. Another method used to achieve lower $\mathrm{NO}_{\mathrm{x}}$ emissions is to fire the coal substoichiometrically and add additional air through overfire air ports. Both of these methods create certain impacts on fireside performance that are different from conventional high-excess-air firing arrangements (1). Some of the impacts that have been noticed by the utility industry are higher levels of unburned carbon in the fly ash and bottom ash, increased boiler tube corrosion, higher particulate loadings on control devices, and changes in slagging in the main furnace $(2,3)$. Work on the fundamental mechanisms of entrained ash and ash deposit formation during low- $\mathrm{NO}_{\mathrm{x}}$ combustion has been sparse. Preliminary work has shown that fly ash particle sizes may actually show an increase in size in the $1-10-\mu \mathrm{m}$ range for low- $\mathrm{NO}_{\mathrm{x}}$ combustion $(1,3,4)$. Also, it was often speculated by the boiler ash research community that the more reducing environment created by this new firing technology would create reduced inorganic phases in the radiant zone of the boiler (5). Reduced mineral species generally have lower melting points and tend to promote more wall slagging or even fouling. However, experience has shown that most utility boilers that have been converted to low- $\mathrm{NO}_{\mathrm{x}}$ burners show very little, if any, fouling problems and usually upper main furnace slagging actually improves. Lower main furnace slagging, however, has increased for boilers that are burning higher-iron coals. It is now believed that decreased upper furnace slagging is due to slightly lower gas temperatures, which essentially suppress the formation of lower-melting-point phases. Increased lower main furnace slagging and eyebrow deposit formation around burners is probably the result of the very high gas temperatures and reducing environment zones that are created in the early combustion stages of low- $\mathrm{NO}_{\mathbf{x}}$ combustion.

This project by the Energy \& Environmental Research Center (EERC) focuses on the issues of entrained ash formation and slagging for low- $\mathrm{NO}_{x}$ combustion systems in general. Timeresolved combustion tests under conventional and low- $\mathrm{NO}_{x}$ conditions have been conducted to note particle-size formation and slagging deposition. Results will be used to support demonstration projects at the utility boiler scale. The results from this work are yielding an increased understanding of the mechanisms of ash formation during low- $\mathrm{NO}_{\mathrm{x}}$ combustion along with methods for enhancing heat transfer and fly ash collectability.

\subsection{OBJECTIVES}

Specific objectives of this research project include 1) determining whether initial char and ash generated under low- $\mathrm{NO}_{\mathrm{x}}$ conditions have greater tendencies for slagging than conventionally generated ash and 2) determining the differences, if any, between particle size and composition for entrained ash generated under low- $\mathrm{NO}_{x}$ and conventional combustion conditions. 
The implications of this research for the industry are clear. If low- $\mathrm{NO}_{\mathrm{x}}$ burners actually decrease slagging and increase collectability of fly ash, then industry will want to take advantage of the benefit, and it will want to know what specific actions need to be taken to trigger the ash formation mechanisms that the EERC has identified. By demonstrating expertise in low- $\mathrm{NO}_{\mathrm{x}}$ combustion ash behavior through these seed efforts, the EERC will encouraged a strong industrial consortium project to further advance the efficient use of low- $\mathrm{NO}_{\mathrm{x}}$ combustion technologies.

\subsection{METHODS}

Extensive combustion tests have already been conducted using a drop-tube furnace to produce conventional and low- $\mathrm{NO}_{\mathrm{x}}$ combustion ash and deposits (1). Work under this project involves using a larger-scale combustion test facility to produce more realistic ash products and verify the previous work. The system used for the combustion testing is the conversion and environmental process simulator (CEPS). The CEPS is an extremely versatile intermediate-scale combustor designed to generate realistic combustion test results for a variety of fuels and combustion conditions. It has a downfired design for nominally top-firing $4.4 \mathrm{lb} / \mathrm{hr}(2 \mathrm{~kg} / \mathrm{hr})$ of pulverized coal with a heat output of $40,000 \mathrm{Btu} / \mathrm{hr}$. It is a modular system capable of simulating conditions of both the radiant and convective sections of a full-scale utility boiler. The vertical radiant furnace portion is $13 \mathrm{ft}$ high inside, with a 6-in. ID reducing down to 3 in. in the final heated section and finally reducing to 2 in. in the furnace exit section prior to the convective section. The combustion air is split and fed as primary and secondary air. The secondary combustion air is preheated to a maximum of $950^{\circ} \mathrm{C}$ and can be introduced into the CEPS vertically or tangentially. Five furnace sections make up the radiant furnace section and are constructed using a combination of ceramic tubes set into cast abrasion-resistant refractory containing sight and sampling ports. The ceramic tubes are exposed to molybdenum disilicide heating elements allowing operation to $1500^{\circ} \mathrm{C}$. High- temperature fibrous insulating boards surround the high-temperature components housed inside the stainless steel shells. A portion of the particulate is removed prior to the combustion gas stream entering the horizontally oriented convective pass. The convective pass is about $4 \mathrm{ft}$ in long and constructed of a combination of ceramic tubing, refractory, and high-temperature fibrous insulating boards. There is the capability for studying deposition in the convective pass with two in-series highly instrumented aircooled probes.

After the convective section, flue gas flows through a heat exchange section and then on to the particulate control device, which is either a baghouse or a cyclone. Flue gas temperatures are well controlled going into the control device section for typical operation between $250^{\circ}$ and $350^{\circ} \mathrm{F}$ $\left(120^{\circ}-175^{\circ} \mathrm{C}\right)$, and flexibility has been built into the system to allow experimentation at even higher flue gas temperatures. Beyond the control device, the flue gas proceeds through an air eductor and up to a stack. There is ample access to the inside of the CEPS for sampling, observation and optical diagnostics through several access ports that penetrate through the ceramic tube reaction zones.

The heating elements are surrounded with state-of-the-art high-temperature fibrous insulating board. Temperatures of the flue gas can attain a maximum of $1500^{\circ}-1600^{\circ} \mathrm{C}\left(2732^{\circ}-2912^{\circ} \mathrm{F}\right)$ in the radiant section and can be maintained at $760^{\circ}-1200^{\circ} \mathrm{C}\left(1400^{\circ}-2200^{\circ} \mathrm{F}\right)$ in the convective pass section. Flue gas flow rates can be maintained at approximately $8 \mathrm{scfm}$ as generated by the combustion of the fuel. The CEPS fabric filtration (baghouse) system shown in Figure 1 has three 


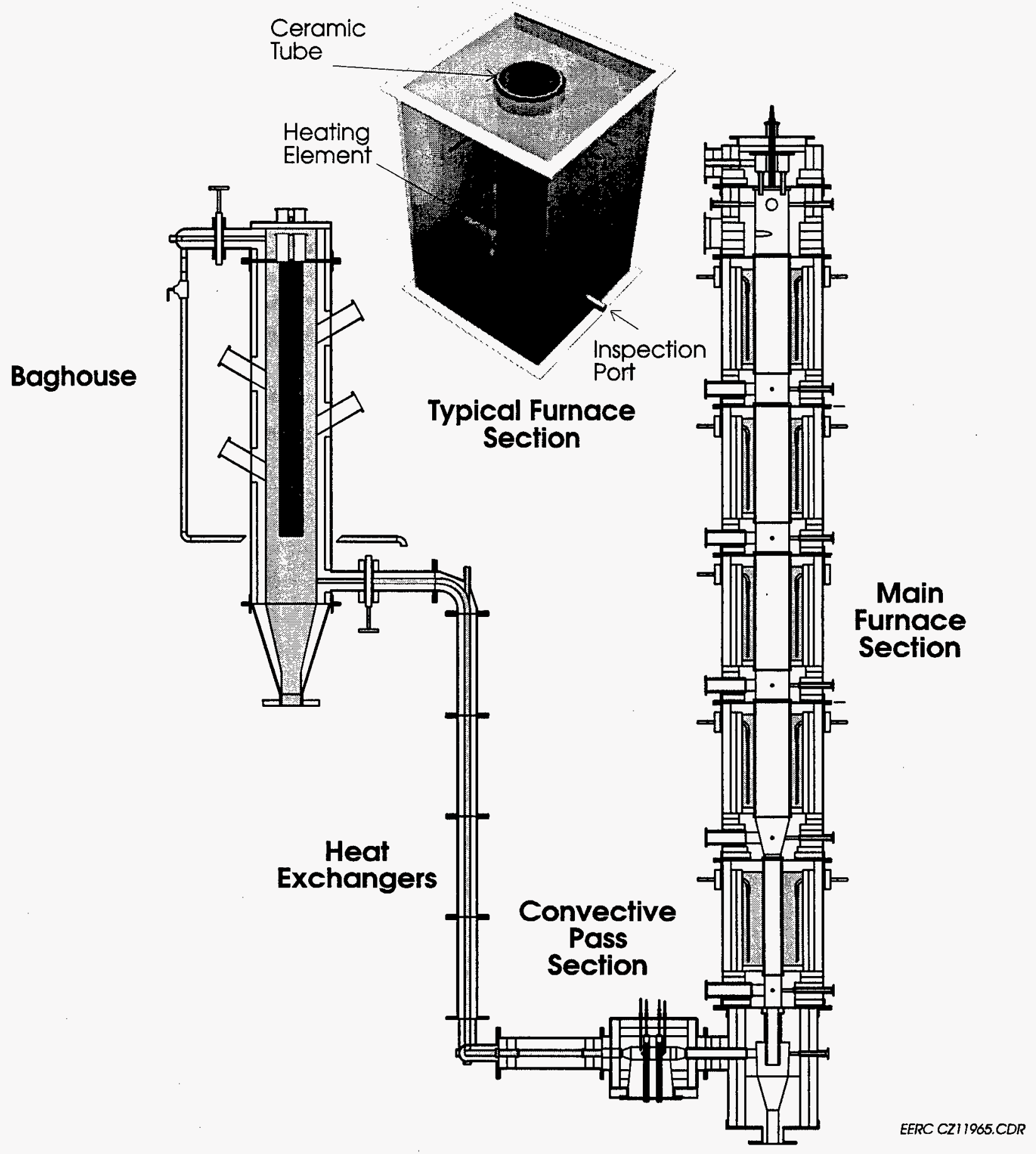

Figure 1. Design sketch of the CEPS showing the main and convective pass sections, heat exchangers, and baghouse.

flanged sections. The main section is an internally insulated and refractory-lined stainless steel shell containing two fabric bags with inside dimensions of $14 \mathrm{in}$. wide by $9 \mathrm{in}$. deep $\times 6 \mathrm{ft}$ high. Both bags are 16-oz Huyglass material 4 in. in diameter $\times 4 \mathrm{ft}$ long with stainless steel cages used to support them. Refractory was selected as an inert lining to prevent contamination of the ash 
generated in the CEPS by contact with metal surfaces prior to its collection. Twelve tubular heaters, slightly less than $1 / 2$ in. in diameter, are inserted horizontally through the refractory walls, allowing the refractory to become radiant heaters to maintain a specified temperature within the baghouse from $300^{\circ}$ to $800^{\circ} \mathrm{F}\left(150^{\circ}\right.$ to $\left.425^{\circ} \mathrm{C}\right)$. There are two isolation ball valves at the inlet and exit to the baghouse to allow the flue gas flow to be bypassed through a stainless steel cyclone when the baghouse is not in operation. The attached collection hopper and exit plenum are also refractory-lined. Nominal operation will result in a gas-to-cloth ratio of 1 . The ratio can be reduced by altering gas flow, by removal of one of the bags, or by physically reducing the length of the installed bag-cage combination. There is a total of six sight ports located throughout the baghouse to permit observation of the buildup of the filter cake on the bag surface. There are two observation ports on the top and four on the sides at various elevations. The bags are cleaned periodically on demand or at timed intervals by a pulse-jet system. The air pressure is regulated to a maximum of $100 \mathrm{psig}$, with normal operation at about $30 \mathrm{psig}$. Thermocouples are used to monitor and record temperatures into, inside, and out of the baghouse. Pressure drops across the baghouse and cyclone are monitored.

The combustion tests for this project were conducted using two different pulverized coals sized at nominally $70 \%-80 \%-200$ mesh fired under conventional and low- $\mathrm{NO}_{\mathrm{x}}$ combustion conditions. Changes made to the primary and secondary gas distributions and furnace temperature profile allowed the CEPS to fire in a low- $\mathrm{NO}_{x}$ combustion mode without structural modifications to the combustor. Furnace operating and test parameters for both conventional and low- $\mathrm{NO}_{\mathrm{x}}$ conditions are discussed in the Results section below.

\subsection{RESULTS}

\subsection{Boiler Industry Review}

A background perusal of utility engineers and operators was undertaken early in the project to determine the nature of slagging and corrosion problems that can be attributed to low- $\mathrm{NO}_{\mathrm{x}}$ combustion technology. The primary concern for many utility boiler operators with low- $\mathrm{NO}_{\mathrm{x}}$ combustion is the potential increase of carbon carryover in the fly ash. Carbon affects both the salability and disposal of fly ash, and many units that have switched to low- $\mathrm{NO}_{x}$ combustion have seen increases of carbon in the ash. Although the focus of this research is on ash formation and deposition, the impact of carbon carryover may be important if it correlates with ash deposition in the boiler. For example, carbon may be playing a role in creating reducing environments in the near-burner region, which would generally pose more of a problem for bituminous coals, which have lower reactivity, because reducing environments are usually associated with greater potential for slag or deposit development.

A survey of the boiler industry seems to show that bituminous coals have more problems with ash deposition; however, it is not clear whether this is due to the usual higher pyrite and iron or to poorer burnout of carbon. Units that have been switched to low- $\mathrm{NO}_{\mathrm{x}}$ burners and are burning subbituminous Powder River Basin coal or low-pyrite (and, consequently, lower-iron) coal, in general, seem to have less lower furnace wall slagging, burner eyebrow formation, and corrosion. It is also clear from examining various boilers that have been retrofitted with low- $\mathrm{NO}_{\mathrm{x}}$ combustion capabilities that the distribution and diffusion of primary, secondary, and overfire air with the coal 
feed stream are critical for proper low- $\mathrm{NO}_{\mathrm{x}}$ operation, as some examples in the utility industry are now surfacing where carbon has actually decreased after a boiler has been converted to low- $\mathrm{NO}_{x}$ burners (3).

Cyclone-fired systems have been given an exemption, at least for the time being, from $\mathrm{NO}_{\mathrm{x}}$ regulations that are being imposed on conventional pulverized coal-fired systems. Therefore, the driving forces are not as great for developing viable technologies to reduce $\mathrm{NO}_{\mathrm{x}}$. Some designs for overfire air or reburn strategies have been tested or implemented, but it may be important to direct future research toward developing more novel options for $\mathrm{NO}_{\mathrm{x}}$ reduction in cyclone boilers. For example, some investigations using additives mixed with the coal and firing into a cyclone under reducing conditions have tried to establish a lower- $\mathrm{NO}_{\mathrm{x}}$ combustion gas. The purpose of the additives would be to keep slag flowing out of the barrel at the lower temperatures under fuel-rich reducing conditions. Other additives may be identified and tested that directly react with combustion gases to lower $\mathrm{NO}_{\mathrm{x}}$.

Finally, it was noted in this limited survey that some utilities are using additives designed to mitigate slag deposition and corrosion by decreasing the production of reduced mineral phases. Additives such as magnesium or manganese oxides and, possibly, lime may act to mitigate the potential for the formation of reduced mineral species that initiate slagging and the formation of corrosive materials, such as pyrrhotite, alkali-iron-trisulfates, or even metallic iron. Other highly oxygenated silicates or oxides may be used as additives also to mitigate by reaction or dilution the formation of reduced mineral phases. The additives may also act to increase carbon combustion efficiency by acting as combustion catalysts.

It was beyond the scope of this project to perform in-depth testing of the effectiveness of additives; however, the understanding being gained with respect to the formation of slag and potentially corrosive ash deposits will provide a sound basis for recommending mitigating measures.

From the brief perusal of industry use of low- $\mathrm{NO}_{\mathrm{x}}$ technologies, it was concluded that research in this project should focus on the following:

- Establishing a protocol for firing the CEPS in a representative low- $\mathrm{NO}_{\mathrm{x}}$ mode.

- Evaluating the role of carbon carryover on ash deposition.

- Evaluating the role of pyrite and iron for combustion of bituminous coal and clays and calcium for combustion of subbituminous coal in the formation of near-burner ash deposits or wall slag.

- Evaluating the fundamental mechanisms of entrained ash and deposit formation in order to make recommendations on the effectiveness of additives such as magnesium oxides on mitigating slagging and corrosion.

- Verifying the previous results of fine ash agglomeration in the larger test scale of the CEPS. 


\subsection{CEPS Conventional and Low- $\mathrm{NO}_{\mathrm{x}}$ Operating Conditions}

The operation of the CEPS combustor was slightly modified to burn the test coals in a low$\mathrm{NO}_{\mathrm{x}}$ combustion mode. Under conventional conditions, $20 \%$ of the total combustor oxygen is injected through the primary air inlet with the balance through the secondary air inlets. To simulate low-NO ${ }_{x}$ conditions all the combustor oxygen is injected through the secondary air inlets, with none through the primary air inlet. A small amount of nitrogen (10\% of the total inlet gas flow) is used to maintain gas velocities and to keep a constant overall gas flow rate. The temperature of the primary and secondary air-nitrogen mixture entering the furnace zone is also lowered by approximately $100^{\circ}$ and $150^{\circ} \mathrm{C}$, respectively, under low- $\mathrm{NO}_{x}$ as compared to conventional conditions, along with a somewhat lower furnace temperature profile. Shakedown and combustion tests resulted in $\mathrm{NO}_{\mathrm{x}}$ reduction of approximately $50 \%$ that of conventional combustion conditions.

\subsection{Combustion Testing}

Two coals were selected for testing under the project, including a subbituminous Black Thunder and a bituminous Illinois No. 6. Properties of these coals are given in Table 1. The Black Thunder coal is fairly typical of coal from the Powder River Basin, with high levels of magnesium and calcium bound organically in the coal, high aluminosilicate as kaolinite or illite clays, and low pyrite, iron, and sulfur. The Illinois No. 6 is typical of eastern U.S. coal, with high pyrite, iron, sulfur, and low quantities of alkali such as calcium. These coals were ground to $80 \%-200$ mesh and fired in the CEPS under conventional and low- $\mathrm{NO}_{\mathrm{x}}$ combustion conditions.

After initial shakedown testing of the CEPS combustor in order to determine the proper low$\mathrm{NO}_{\mathrm{x}}$ combustion arrangement, the Black Thunder and Illinois No. 6 coals were then fired in the CEPS under conventional and low- $\mathrm{NO}_{\mathrm{x}}$ conditions. During combustion testing, on-line measurements of $\mathrm{NO}_{\mathrm{x}}, \mathrm{SO}_{\mathrm{x}}, \mathrm{CO}_{2}$, and $\mathrm{O}_{2}$ were performed using gas analyzers, and on-line particlesize measurements made using an aerodynamic particle sizer (APS) and a differentual mobility particle sizer (DMPS). Entrained ash was sampled from the high-temperature zone $\left(1270^{\circ}-1300^{\circ} \mathrm{C}\right)$ in the near-burner region and from the low-temperature zone $\left(150^{\circ}-250^{\circ} \mathrm{C}\right)$ at the entrance to the baghouse collector. The on-line particle size measurements were also performed at the baghouse entrance. Slag deposits were collected on uncooled ceramic probes at the same point in the high-temperature zone as the entrained ash samples were obtained. Table 2 gives the furnace parameters and other conditions for the combustion tests.

The entrained ash samples were analyzed using computer-controlled scanning electron microscopy (CCSEM) to determine the ash chemical composition and size on a particle-by-particle basis. The analogous scanning electron microscopy point count (SEMPC) analysis method was used to examine the slag deposits obtained from the near-burner region. The morphologies of both deposits and entrained ash samples were also examined using the scanning electron microscope (SEM). Table 3 gives the CCSEM results for the coals under conventional and low- $\mathrm{NO}_{\mathrm{x}}$ test conditions. As found previously in the smaller drop-tube furnace tests, there is no major change in mineral composition due to the low- $\mathrm{NO}_{\mathrm{x}}$ conditions. The Black Thunder ash has a high percentage of "unknown" material, apparently resulting from agglomeration of the entrained ash as it was drawn into the particulate collection probe. The SEMPC analysis of the slag deposits appears in Table 4. The Black Thunder slag shows an increase in mixed silicon-rich phases and a decrease in what has been characterized by the mineral classifications program as montmorillonite under low- 


\section{TABLE 1}

Analysis of Test Coals

\begin{tabular}{lcc}
\hline & Black Thunder & Illinois No. \\
\hline Proximate & & \\
Moisture & 24.30 & 11.70 \\
Volatile Matter & 35.88 & 34.97 \\
Fixed Carbon & 35.32 & 43.39 \\
Ash & 4.49 & 9.95 \\
Ultimate & & \\
Hydrogen & 7.04 & 5.34 \\
Carbon & 52.84 & 61.99 \\
Nitrogen & 0.70 & 1.05 \\
Sulfur & 0.39 & 2.85 \\
Oxygen & 34.54 & 18.8 \\
$\mathrm{Ash}$ & 4.49 & 9.95 \\
Elemental Oxides, wt\% & & \\
$\mathrm{SiO} \mathrm{O}_{2}$ & 32.57 & 23.54 \\
$\mathrm{Al}_{2} \mathrm{O}_{3}$ & 16.81 & 9.21 \\
$\mathrm{Fe}_{2} \mathrm{O}_{3}$ & 5.69 & 12.33 \\
$\mathrm{TiO}_{2}$ & 1.11 & 0.41 \\
$\mathrm{P}_{2} \mathrm{O}_{5}$ & 1.17 & 0.04 \\
$\mathrm{CaO}$ & 22.09 & 1.45 \\
$\mathrm{MgO}^{\mathrm{NaO}}$ & 4.79 & 0.67 \\
$\mathrm{~K}_{2} \mathrm{O}$ & 0.93 & 0.41 \\
$\mathrm{SO}_{3}$ & 0.15 & 1.00 \\
$\mathrm{Minerals,} \mathrm{wt \%} \mathrm{mineral} \mathrm{basis}_{\mathrm{Quart}}$ & 14.69 & 50.95 \\
$\mathrm{Kaolinite}_{\mathrm{Illite}}$ & & \\
$\mathrm{Pyrite}_{\mathrm{Other}}$ & 24.1 & 23.30 \\
\hline & 29.1 & 13.80 \\
& 0.70 & 12.20 \\
& 4.70 & 26.70 \\
& 41.40 & 24.00 \\
\hline
\end{tabular}

$\mathrm{NO}_{\mathrm{x}}$ conditions, while the opposite is seen for the Illinois No. 6 slag. As the slags were seen both visually and under the SEM to be quite homogenous and having passed through a molten state, the "montmorillonite" identified appears to be a silica-alumina melt with that approximate composition. The bulk chemical compositions of both slags show an increase in silica, with a concurrent decrease in alumina and iron under low- $\mathrm{NO}_{\mathrm{x}}$ as opposed to conventional combustion conditions. The decrease in iron content is particularly striking for the Illinois No. 6 slag. The higher temperatures associated with the conventional combustion conditions appear to allow more high-alumina and -iron ash particles to become incorporated into the slag melt. The morphology of the Black Thunder slag produced under low- $\mathrm{NO}_{\mathrm{x}}$ conditions also revealed more discrete particles on the slag surface that had not yet been incorporated into the molten phase. The detailed particle-by-particle analysis data are being examined for evidence of reduced species that may have formed under low- $\mathrm{NO}_{\mathrm{x}}$ conditions. 
TABLE 2

Combustion Test Conditions

\begin{tabular}{|c|c|c|c|c|}
\hline Parameter & $\begin{array}{c}\text { Black Thunder, } \\
\text { conventional }\end{array}$ & $\begin{array}{c}\text { Black Thunder, } \\
\text { low } \mathrm{NO}_{x}\end{array}$ & $\begin{array}{c}\text { Illinois No. } 6 \text {, } \\
\text { conventional }\end{array}$ & $\begin{array}{c}\text { Illinois No. } 6 \text {, } \\
\text { low } \mathrm{NO}_{x}\end{array}$ \\
\hline \multicolumn{5}{|l|}{ Furnace Set Points, ${ }^{\circ} \mathrm{C}$} \\
\hline Preheater & 1000 & 800 & 1000 & 800 \\
\hline Furnace 3 & 1500 & 1300 & 1500 & 1300 \\
\hline Furnace 4 & 1500 & 1350 & 1500 & 1350 \\
\hline Furnace 5 & 1450 & 1400 & 1450 & 1400 \\
\hline Furnace 6 & 1450 & 1400 & 1450 & 1400 \\
\hline Furnace 7 & 1200 & 1200 & 1200 & 1200 \\
\hline \multicolumn{5}{|c|}{ Furnace Temperatures, ${ }^{\circ} \mathrm{C}$} \\
\hline Preheater Air & 777 & 624 & 776 & 624 \\
\hline Secondary Air & 615 & 504 & 618 & 506 \\
\hline Section 2 & 1108 & 962 & 1139 & 998 \\
\hline Section 3 & 1360 & 1313 & 1369 & 1315 \\
\hline Section $4 *$ & 1308 & 1268 & 1315 & 1281 \\
\hline Section 5 & 1368 & 1313 & 1362 & 1311 \\
\hline Section 6 & 1342 & 1300 & 1339 & 1297 \\
\hline Section 7 & 1065 & 1033 & 1072 & 1022 \\
\hline Section 8 & 998 & 923 & 997 & 856 \\
\hline Baghouse Inlet** & 248 & 151 & 237 & 163 \\
\hline $\mathrm{NO}_{x}$ Level, ppm & 995 & 370 & 815 & 378 \\
\hline \multicolumn{5}{|l|}{ Gas Flows, slpm } \\
\hline Primary Air & 31 & 0 & 31 & 0 \\
\hline Primary Nitrogen & 0 & 16 & 0 & 16 \\
\hline Secondary Air & 120 & 151 & 120 & 151 \\
\hline Secondary Nitrogen & 16 & 0 & 16 & 0 \\
\hline Purge Air & 3 & 3 & 3 & 3 \\
\hline Total Air & 154 & 154 & 154 & 154 \\
\hline Total Gas & 170 & 170 & 170 & 170 \\
\hline Coal Feed Rate, kg/hr & 1.395 & 1.318 & 1.055 & 0.999 \\
\hline
\end{tabular}

* Slag and near-burner entrained ash sample point.

**Baghouse entrained ash and on-line size analysis sample point.

The data from the on-line particle size analyses conducted during the tests are in the process of being reduced. Table 3 gives the particle-size distributions obtained from the CCSEM analysis of the entrained ash from the near-burner region and from the baghouse inlet. The low-temperature 
TABLE 3

Entrained Ash Analysis

\begin{tabular}{|c|c|c|c|c|c|c|c|c|}
\hline Mineral & $\begin{array}{c}\text { Black Thunder, } \\
\text { conventional } \\
\text { near-burner }\end{array}$ & $\begin{array}{l}\text { Black Thunder, } \\
\text { low } \mathrm{NO}_{\mathrm{x}} \\
\text { near-burner }\end{array}$ & $\begin{array}{c}\text { Black Thunder, } \\
\text { conventional } \\
\text { baghouse }\end{array}$ & $\begin{array}{c}\text { Black Thunder, } \\
\text { low } \mathrm{NO}_{\mathrm{x}} \\
\text { baghouse }\end{array}$ & $\begin{array}{c}\text { Illinois No. } 6 \text {, } \\
\text { conventional } \\
\text { near-burner }\end{array}$ & $\begin{array}{c}\text { Illinois No. } 6 \text {, } \\
\text { low } \mathrm{NO}_{\mathrm{x}} \\
\text { near-burner }\end{array}$ & $\begin{array}{c}\text { Illinois No. } 6 \text {, } \\
\text { conventional } \\
\text { baghouse }\end{array}$ & $\begin{array}{c}\text { Illinois No. } 6, \\
\text { low } \mathrm{NO}_{\mathrm{x}} \\
\text { baghouse }\end{array}$ \\
\hline Quartz & 3.3 & 3.4 & 10.3 & 8.7 & 7.3 & 12.3 & 12.1 & 12.9 \\
\hline Iron Oxide & 0.0 & 0.3 & 0.0 & 0.1 & 0.9 & 2.9 & 5.5 & 6.5 \\
\hline Periclase & 0.0 & 0.0 & 0.0 & 0.0 & 0.0 & 0.0 & 0.0 & 0.0 \\
\hline Rutile & 0.0 & 0.0 & 0.0 & 0.5 & 0.2 & 0.2 & 0.0 & 0.1 \\
\hline Alumina & 0.0 & 0.0 & 0.1 & 0.2 & 0.0 & 0.0 & 0.0 & 0.0 \\
\hline Calcite & 0.0 & 0.1 & 0.9 & 0.9 & 0.3 & 1.1 & 2.1 & 4.7 \\
\hline Dolomite & 0.4 & 0.0 & 1.9 & 1.8 & 0.0 & 0.0 & 0.1 & 0.0 \\
\hline Ankerite & 0.1 & 0.2 & 0.1 & 0.3 & 0.0 & 0.2 & 0.0 & 0.2 \\
\hline Kaolinite & 0.4 & 0.9 & 3.3 & 3.8 & 7.4 & 19.4 & 11.3 & 13.6 \\
\hline Montmorillonite & 0.0 & 0.3 & 0.2 & 0.8 & 7.5 & 8.3 & 10.5 & 10.4 \\
\hline K Al-Silicate & 0.0 & 0.3 & 2.2 & 1.7 & 5.6 & 11.4 & 12.4 & 11.4 \\
\hline Fe Al-Silicate & 0.0 & 0.0 & 0.1 & 0.4 & 24.4 & 10.0 & 13.6 & 8.4 \\
\hline Ca Al-Silicate & 9.5 & 9.9 & 15.1 & 10.2 & 1.5 & 2.6 & 1.7 & 2.8 \\
\hline Na Al-Silicate & 0.0 & 0.9 & 0.0 & 1.2 & 0.0 & 0.0 & 0.0 & 0.0 \\
\hline Aluminosilicate & 0.0 & 0.0 & 0.2 & 0.4 & 2.5 & 2.5 & 3.8 & 1.9 \\
\hline Mixed Al-Silica & 0.0 & 1.1 & 0.8 & 1.8 & 5.7 & 3.9 & 3.3 & 2.8 \\
\hline Fe Silicate & 0.0 & 0.0 & 0.0 & 0.0 & 0.2 & 0.3 & 0.8 & 0.9 \\
\hline Ca Silicate & 1.7 & 0.8 & 4.1 & 3.5 & 0.1 & 0.0 & 0.2 & 0.2 \\
\hline Ca Aluminate & 6.2 & 8.4 & 11.4 & 13.8 & 0.0 & 0.0 & 0.0 & 0.0 \\
\hline Pyrite & 0.0 & 0.0 & 0.0 & 0.0 & 0.0 & 0.0 & 0.0 & 0.0 \\
\hline Pyrrhotite & 0.0 & 0.0 & 0.0 & 0.0 & 0.0 & 0.1 & 0.1 & 0.0 \\
\hline Oxidized Pyrrhotite & 0.0 & 0.0 & 0.0 & 0.0 & 0.0 & 0.6 & 0.4 & 0.8 \\
\hline Gypsum & 1.9 & 2.8 & 0.1 & 0.0 & 5.5 & 1.3 & 0.3 & 1.0 \\
\hline Barite & 0.0 & 0.0 & 0.0 & 0.0 & 0.0 & 0.0 & 0.0 & 0.0 \\
\hline Apatite & 0.0 & 0.0 & 0.0 & 0.2 & 0.0 & 0.1 & 0.0 & 0.0 \\
\hline Ca Al-P & 0.1 & 0.3 & 0.2 & 1.1 & 0.0 & 0.0 & 0.0 & 0.0 \\
\hline $\mathrm{KCl}$ & 0.0 & 0.0 & 0.0 & 0.0 & 0.0 & 0.0 & 0.0 & 0.0 \\
\hline Gypsum-Barite & 0.0 & 0.0 & 0.0 & 0.0 & 0.0 & 0.0 & 0.0 & 0.0 \\
\hline Gypsum-AI-Silicate & 10.8 & 7.4 & 5.1 & 2.1 & 3.3 & 1.4 & 1.0 & 0.2 \\
\hline Si-Rich & 0.1 & 1.2 & 0.4 & 1.4 & 6.3 & 4.9 & 5.3 & 6.3 \\
\hline Ca-Rich & 1.2 & 0.7 & 1.5 & 2.5 & 0.1 & 0.6 & 1.5 & 0.9 \\
\hline Ca-Si-Rich & 0.4 & 0.8 & 0.9 & 1.8 & 0.1 & 0.1 & 0.0 & 0.0 \\
\hline Unknown & 64.2 & 60.1 & 41.2 & 40.3 & 21.0 & 15.9 & 14.0 & 14.0 \\
\hline \multicolumn{9}{|l|}{ Size, $\mu \mathrm{m}$} \\
\hline $1.0-2.2$ & 8.3 & 14.5 & 27.3 & 18.7 & 9.2 & 32.2 & 14.7 & 27.5 \\
\hline $2.2-4.6$ & 25.3 & 37.7 & 33.9 & 28.7 & 61.4 & 51.3 & 34.5 & 29.5 \\
\hline $4.6-10.0$ & 25.4 & 21.8 & 15.6 & 34.8 & 17.8 & 9.2 & 29.6 & 29.9 \\
\hline $10.0-22.0$ & 19.9 & 17.8 & 17.4 & 15.2 & 8.3 & 5.5 & 18.5 & 11.4 \\
\hline $22.0-46.0$ & 10.7 & 4.8 & 5.5 & 2.6 & 1.9 & 1.6 & 2.4 & 1.5 \\
\hline $46.0-100.0$ & 10.3 & 3.5 & 0.3 & 0.1 & 1.4 & 0.3 & 0.3 & 0.2 \\
\hline
\end{tabular}


TABLE 4

SEMPC Analysis of Slag Deposits

\begin{tabular}{|c|c|c|c|c|}
\hline $\begin{array}{l}\text { Coal } \\
\text { Condition } \\
\end{array}$ & $\begin{array}{c}\text { Black Thunder, } \\
\text { conventional }\end{array}$ & $\begin{array}{l}\text { Black Thunder, } \\
\text { low } \mathrm{NO}_{x}\end{array}$ & $\begin{array}{c}\text { Illinois No. } 6, \\
\text { conventional }\end{array}$ & $\begin{array}{c}\text { Illinois No. 6, } \\
\text { low- } \mathrm{NO}_{\mathrm{x}}\end{array}$ \\
\hline \multicolumn{5}{|l|}{ Mineral, wt\% } \\
\hline \multicolumn{5}{|l|}{ Oxide-Rich } \\
\hline Aluminum Oxide & 0.0 & 0.0 & 2.0 & 0.0 \\
\hline Mixed Oxide-Rich & 0.0 & 0.0 & 0.8 & 0.0 \\
\hline Trotal: & 0.0. & 0.0 & 2.8 & 0.0 \\
\hline \multicolumn{5}{|l|}{ Silicon-Rich } \\
\hline Quartz & 0.0 & 0.0 & 0.4 & 4.8 \\
\hline Kaolinite & 0.0 & 0.4 & 0.0 & 0.8 \\
\hline Altered Kaolinite & 2.4 & 0.8 & 5.2 & 0.4 \\
\hline Montmorillonite & 94.8 & 80.0 & 4.8 & 77.2 \\
\hline Wollastonite & 0.0 & 0.0 & 0.4 & 0.0 \\
\hline Mullite & 0.0 & 0.0 & 0.4 & 0.0 \\
\hline Mixed Silicon-Rich & 2.4 & 8.8 & 86.0 & 15.2 \\
\hline Total: & 99.6 & 99.6 & 97,2 & 98.4 \\
\hline Other & 0.4 & 0.4 & 0.0 & 1.6 \\
\hline \multicolumn{5}{|c|}{ Bulk Sample Composition } \\
\hline \multicolumn{5}{|c|}{ Element, oxide wt\% } \\
\hline $\mathrm{SiO}_{2}$ & 52.9 & 61.6 & 35.9 & 59.9 \\
\hline $\mathrm{Al}_{2} \mathrm{O}_{3}$ & 26.5 & 17.6 & 27.6 & 18.4 \\
\hline $\mathrm{Fe}_{2} \mathrm{O}_{3}$ & 9.0 & 7.1 & 26.2 & 8.1 \\
\hline $\mathrm{TiO}_{2}$ & 0.9 & 1.0 & 0.4 & 1.0 \\
\hline $\mathrm{P}_{2} \mathrm{O}_{5}$ & 0.1 & 0.4 & 0.1 & 0.3 \\
\hline $\mathrm{CaO}$ & 7.3 & 8.9 & 6.7 & 8.8 \\
\hline $\mathrm{MgO}$ & 1.4 & 1.7 & 0.9 & 1.8 \\
\hline $\mathrm{Na}_{2} \mathrm{O}$ & 1.3 & 1.0 & 0.5 & 1.1 \\
\hline $\mathrm{K}_{2} \mathrm{O}$ & 0.5 & 0.5 & 1.5 & 0.5 \\
\hline $\mathrm{SO}_{3}$ & 0.0 & 0.1 & 0.1 & 0.1 \\
\hline
\end{tabular}

Black Thunder entrained ash shows a decrease in the smallest particle sizes under low- $\mathrm{NO}_{\mathrm{x}}$ as compared to conventional conditions, while the Illinois No. 6 shows a modest increase in the finer size fractions. These results are consistent with previous results from small-scale drop-tube furnace tests. The high-temperature near-burner entrained ashes show the opposite trend, with the finer Black Thunder particle-size fractions increasing and the Illinois No. 6 fractions decreasing under low- $\mathrm{NO}_{\mathrm{x}}$ conditions. The high-temperature entrained ash results are apparently skewed by the formation of very large agglomerates formed during the collection of the entrained ash. The 
morphological examination of the entrained ash samples revealed many such agglomerates of $100 \mu \mathrm{m}$ or greater made up of agglomerations of much smaller ash particles.

\subsection{CONCLUSIONS}

A standard test protocol has been developed for firing the CEPS in the conventional and low$\mathrm{NO}_{\mathrm{x}}$ modes by changing oxygen concentrations in the primary and secondary inlet air streams and changing the furnace temperature profile. The $\mathrm{NO}_{\mathrm{x}}$ levels under simulated low- $\mathrm{NO}_{\mathrm{x}}$ combustion conditions are reduced to approximately half those under conventional combustion conditions.

Based on the experimental approach and test plan established for this work, combustion tests with Black Thunder and Illinois No. 6 coals have been performed in the CEPS under conventional and low- $\mathrm{NO}_{\mathrm{x}}$ conditions. Slag deposits were collected in the high-temperature zone corresponding to a utility boiler near-burner region and entrained ash deposits obtained from this high temperature zone and from the low-temperature entrance to the CEPS baghouse. In conjunction with these samples, on-line particle size measurements were made at the baghouse entrance.

The ash and slag samples obtained were examined and analyzed for particle size and chemical and mineral composition. No great changes in the compositions of the entrained ash samples were observed between conventional and low- $\mathrm{NO}_{\mathrm{x}}$ combustion conditions. The slags produced show an increase in bulk silica and a decrease in bulk alumina and iron under low- $\mathrm{NO}_{\mathrm{x}}$ conditions. The CCSEM particle-size distributions for the low-temperature entrained ash collected at the baghouse inlet shows a decrease in the finest particles sizes for the Black Thunder coal, but not for the Illinois No. 6 coal, consistent with earlier small-scale drop-tube furnace studies. The hightemperature near-burner entrained ash size distributions are biased to larger particle sizes by the presence of large ash agglomerates formed during the collection process. An evaluation is being made concerning the role of carbon carryover on ash deposition and the role of pyrite, iron, clays, and calcium in the formation of near-burner ash deposits or wall slag.

\subsection{FUTURE WORK}

After completing combustion tests and a thorough examination of the key fundamental aspects of ash formation and deposition under low- $\mathrm{NO}_{\mathrm{x}}$ combustion conditions, we will propose follow-on work to conduct more rigorous studies at full-scale utility boilers to verify the results and to identify practical solutions to slagging and corrosion problems. Testing additives for effectiveness in mitigating slag formation or corrosivity of deposits is a subject of future research. Other methods for mitigation should also be tested, such as varying the firing arrangement or attempting to eliminate local reducing zones in the near-burner regions or waterwall areas where deposition frequently occurs, by blowing streams of air on experimental deposits being generated under reducing conditions to determine whether corrosive slag development can be mitigated with the strategic positioning of air lances. 


\subsection{REFERENCES}

1. Zygarlicke, C.J.; McCollor, D.P.; Toman D.L.; Wall, T.F.; Gupta, R.P.; Razaei, H. "A Comparison of Ash Produced Under Conventional and Low- $\mathrm{NO}_{\mathrm{x}}$ Combustion Conditions," In Proceedings of the 1995 International Joint Power Generation Conference: Vol. 1 Environmental Control/Fuels and Combustion Technologies; Smouse, S.M.; Frazier, W.F., Eds.; ASME: New York, NY, 1995; pp 449-462.

2. Makansi, J. "Reducing $\mathrm{NO}_{\mathrm{x}}$ Emissions from Today's Powerplants," Power 1993, May, 11-28.

3. Hower, J.C.; Robl, T.L.; Rathbone, R.F. "Carbon Content of Pre- and Post-NO Conversion Fly Ash: Experience at Tennessee Valley Authority's John Sevier Fossil Plant," In Proceedings of the 2nd Conference on Unburned Carbonaceous Material on Utility Fly Ash; March 5-6, 1996, Pittsburgh, PA; 1996, pp 15-26.

4. Robl, T.L.; Groppo, J.G.; Brooks, S.; Hower, J.C. "Case Studies of Low-NO Burner Retrofit: I. The Effect of Loss on Ignition, Particle Size and Chemistry of the Fly Ash," In Proceedings of the 11th International Symposium on Use and Management of Coal Combustion By-Products (CCBs); January 1995, Orlando, FL; American Coal Ash Society: TR-104657-V1, Research Project 3176, 1995, Vol. 1, pp 21-1-21-12.

5. Baxter, L.L. "The Effect of Low-NO $\mathrm{N}_{x}$ Firing on Fireside Performance," Presented at the Engineering Foundation Conference on the Economic and Environmental Aspects of Coal Utilization VI, Santa Barbara, CA, Jan. 29-Feb. 2, 1995. 
J:BAY4T304,WK4

FORM EIA-459E

$(10 / 88)$
U.S DEPARTMENT OF ENERGY

FEDERAL ASSISTANCE MANAGEMENT SUMMARY REPORT

FORM APPROVED

OMB NO. 19000127

Page 1 of 2

1. Program/Project Identification No.

DE-FC21-93MC30097

4. Name and Address
2. Program/Project Title

TASK 3.0 ADVANCED POWER SYSTEMS

Energy \& Environmental Research Center

University of North Dakota

PO Box 9018, Grand Forks, ND $58202-9018$ (701) 777-5000
Period

10-1-96 through $12-31-96$

5. Program Start Date

$01-12-93$

6. Completion Date

$12-31-97$

\begin{tabular}{|c|c|}
\hline $\begin{array}{c}\text { 7. FY } \\
96 / 97\end{array}$ & $\begin{array}{c}\text { 8. Months or Quarters } \\
\text { Quarters }\end{array}$ \\
\hline $\begin{array}{l}\text { 9. Cost } \\
\text { Status }\end{array}$ & a. Dollars Expressed In \\
Thousands
\end{tabular}

10. Cost Chart

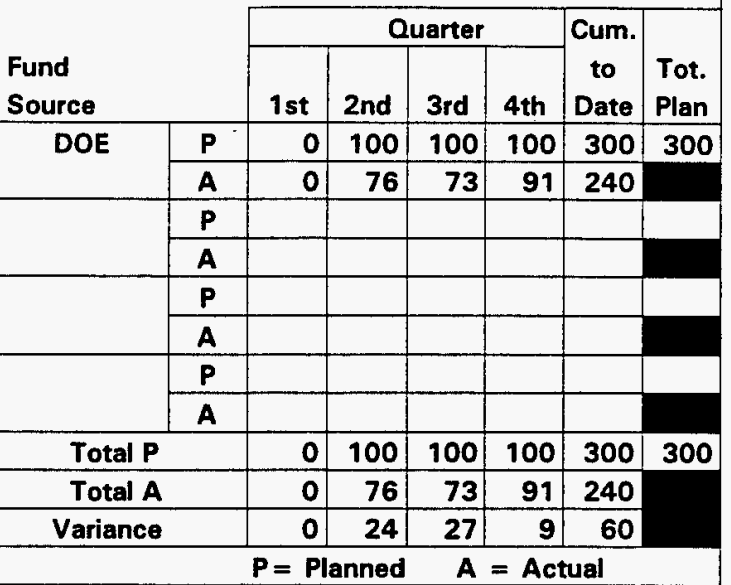

\begin{tabular}{|c|c|c|c|c|c|c|c|c|c|c|c|c|}
\hline \multirow{2}{*}{$\begin{array}{l}\text { b. Dollar } \\
\text { Scale }\end{array}$} & \multicolumn{3}{|l|}{$1 \mathrm{st}$} & \multicolumn{3}{|l|}{ 2nd } & \multicolumn{3}{|l|}{ 3rd } & \multicolumn{3}{|l|}{ 4th } \\
\hline & JAN & FEB & MAA & APR & MAY & JUN & JUL. & AUG & SEP & OCT & NOV & DE \\
\hline
\end{tabular}

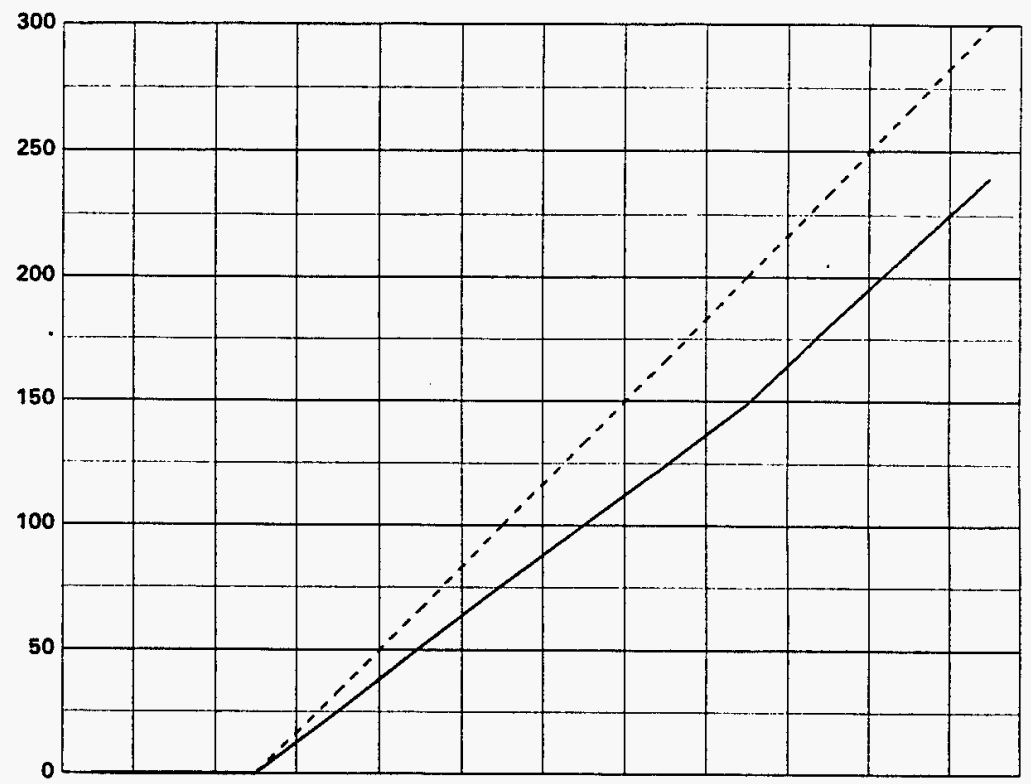

c. Cumulative Accrued Costs

Total Planned Costs for Program/Project

$\$ 300$

\begin{tabular}{|l|r|r|r|r|r|r|r|r|r|r|r|}
\hline Planned & & 0 & & 100 & & & 200 & & & 300 \\
\hline Actual & & & 0 & & & 76 & & & 149 & & \\
\hline Variance & & 0 & & & 24 & & & 51 & & & 60 \\
\hline
\end{tabular}

11. Major Milestone Status

3.12 Small Power Systems Commercialization Plan

3.15 Impacts of Low-NOx Combustion Fly Ash and Slagging

3.16 Low-Cost CWF for Entrained Flow Gasification

3.17 Hot-Gas Cleanup

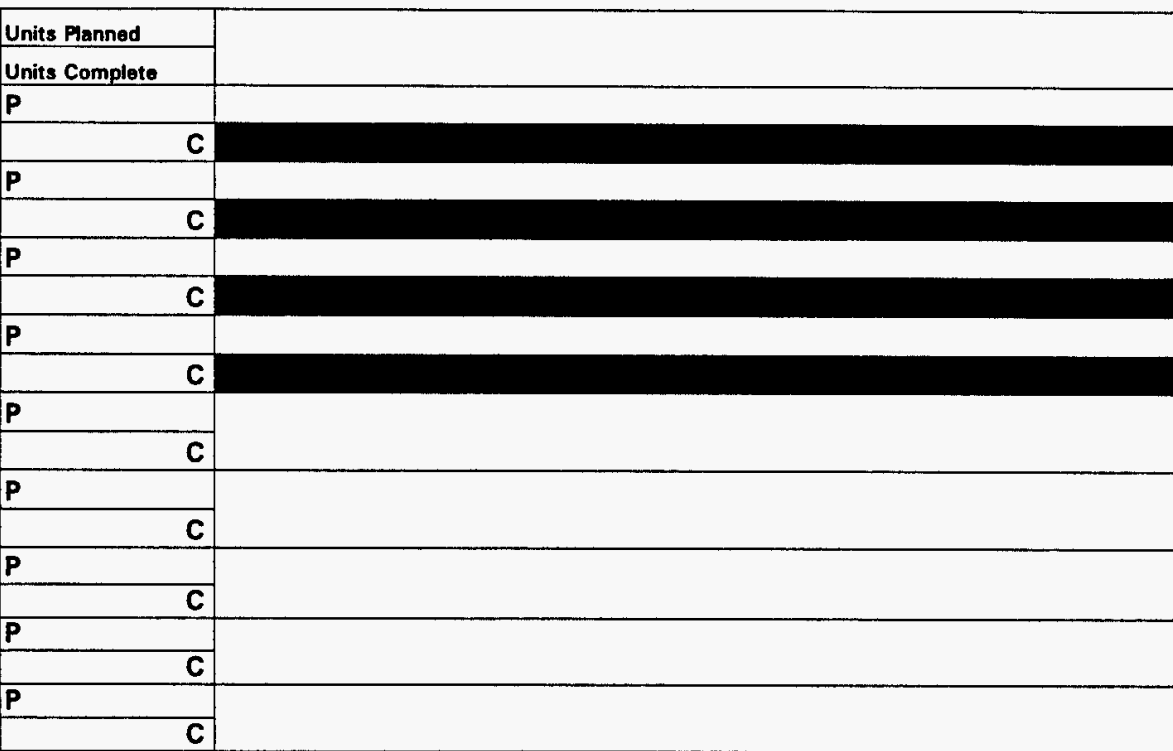

\section{Remarks}

13: Signatupe of Rlecipient and Date
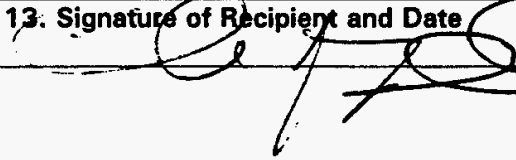

14. Signature of DOE Reviewing Representative and Date 


\section{U.S. DEPARTMENT OF ENERGY}

FORM EIA-459E

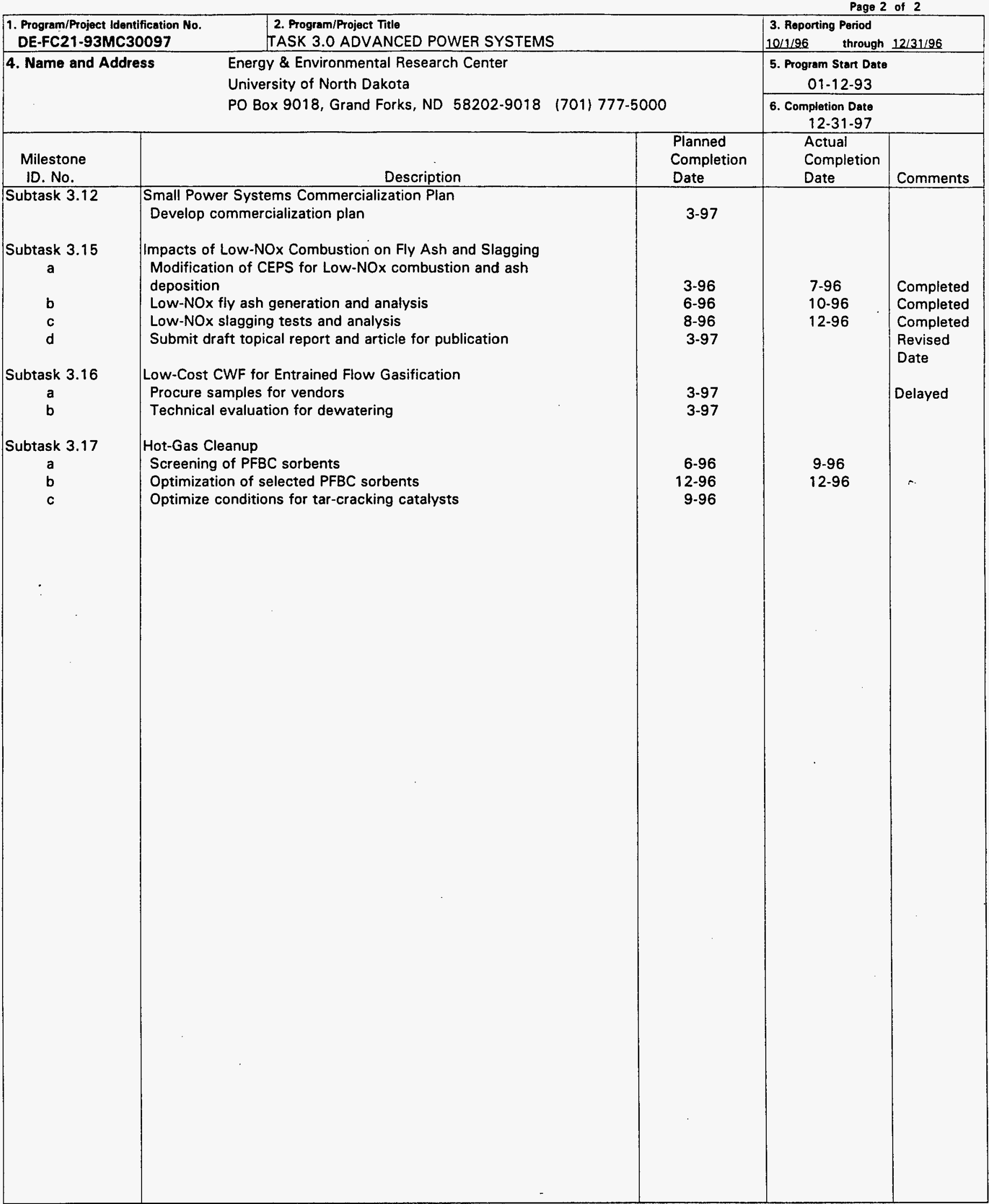


M97002234

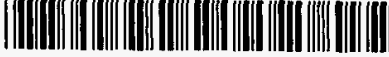

Report Number (14)DOE/MC/30097- 5587

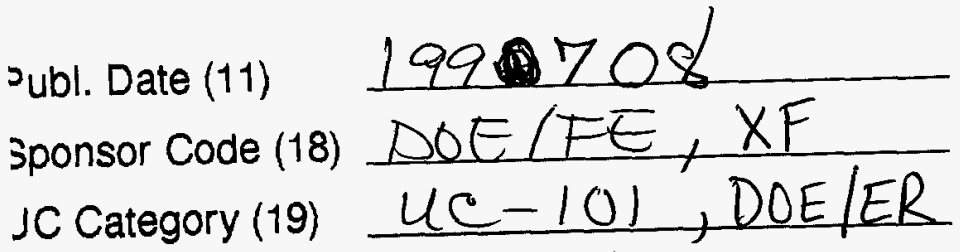

